\title{
A Study of HIV Disease Course among Rural Women Receiving ART
}

\author{
Gayathri V', Ramanamma VM² \\ ${ }^{1}$ Gayathri Veluri, Associate Professor in Microbiology Department of Microbiology, NRI Institute of Medical Sciences, \\ Sanghivalasa, Visakhapatnam, Andhra Pradesh, India and ${ }^{2}$ Ramanamma.VenkataMallajosyula, MD (Microbiology) Rector , \\ Dr.NTR University of Health Sciences, Vijayawada - 520008, Andhra Pradesh, India.
}

Address for correspondence: Dr Gayathri Veluri, Email: drgayathrimicro@gmail.com

\begin{abstract}
Introduction: The present study is an attempt to evaluate and document HIV incidence and progression among women in and around Srikakulam, a remote town in the north coastal Andhra Pradesh. The results throw light on a greater effort required to be mobilized towards preventive and therapeutic care in women in rural areas. Material \& Methods: This is a retrospective study, using the data collected from ICTC (from April 2007 to March 2011) and ART center (from April 2007 to February 2010) of RIMS General Hospital, Srikakulam. The study is focused on the development of $\mathrm{CD}_{4}$ counts at regular intervals among women on ART. Opportunistic infections, deaths, transfers and the profiles of $\mathrm{CD}_{4}$ counts have also been analyzed. Results: There is a significant percentage of responsiveness to therapy in the younger age group. Tuberculosis is significant in being the commonest opportunistic infection causing death with a percentage of 16.4. Maximum number of deaths (27.8\%) were associated with $\mathrm{CD}_{4}$ counts as low as $0-50$ per cu mm, and there is a decrease in the percentages of deaths at higher range of $\mathrm{CD}_{4}$ counts. As a baseline parameter, the $\mathrm{CD}_{4}$ counts of $50 \mathrm{HIV}$ seronegative women between the ages of 15-45 years are estimated. The average is 972 cells /cumm. Conclusion: In spite of an overall decrease in the severity of the epidemic, the problem persists among women in the rural set up. The present study throws light on the need of special programmes which focus on early detection, early initiation of ART, counseling regarding barrier methods applicable to females and monitoring therapy in women.
\end{abstract}

Key Words :HumanImmuno Deficiency Virus, Anti Retro Viral Therapy, Integrated Counseling and Testing Center ( ICTC) , $\mathrm{CD}_{4}$ counts, National AIDS Control Organisation ( NACO),Opportunistic infections (OI), Highly active anti retro viral therapy (HAART).

\section{Introduction}

HIV infection in a developing country like India is unique, as the progressive ill health is projected on a background of poverty and inadequate medical care. Among the HIV infected, women in India suffer more on account of social, cultural, economic, biological and

Manuscript received: $10^{\text {th }}$ Sep 2013

Reviewed: $16^{\text {th }}$ Sep 2013

Author Corrected: $30^{\text {th }}$ Sep 2013

Accepted for Publication: $1^{\text {st }}$ Oct 2013 clinical factors which keep females at a higher risk $^{1}$. Women in India are mostly illiterate and financially depend on others for their nutrition and health ${ }^{2}$. Majority of HIV seropositive women in India are married and reported monogamous ${ }^{3}$. Vertical transmission from a pregnant women to the fetus is well documented ${ }^{4}$. HIV infection among women is associated with a greater than two fold 
risk of having cervical cancer, $\mathrm{TB}$, invasive candidiasis and many other Opportunistic Infections.

Triple drug therapy (HAART) alone can significantly alter HIV disease progression. The challenging issues in India are inadequately trained human resources and the incapacity of the health system to utilize ART drugs optimally along with inadequate training of health care personnel, laboratory monitoring and drug distribution.

The present place of study is a small town in the North East of Andhra Pradesh surrounded by a number of satellite villages and tribal areas. Anti Retroviral Therapy (ART) centre has been established in the hospital, in March 2007.

As per the NACO guidelines, all the seropositive individuals are referred to ART centre, where they are counseled and baseline $\mathrm{CD}_{4}$ counts are done.

Those with $\mathrm{CD}_{4}$ counts of less than $250 / \mathrm{mm}^{3}$ are started on ART and are followed up on regular basis at every six month interval.
The present retrospective study is undertaken at ART centre, in the tertiary care hospital. Detailed information was collected about all women who attended the ART centre from the date of inception, up to 03 visits (one and a half years).

All the factors determining the clinical course of HIV are analyzed. The results of the present study throw light on the issues to be solved and methodologies to be developed to contain HIV infection among women in India.

\section{Material and Methods}

The data collected at ICTC and ART Center (April 2007 to March 2011) is included in the present study. The critical analysis of the data is focused on the development of $\mathrm{CD}_{4}$ counts at regular intervals among women on ART. Opportunistic infections, deaths, transfers and the profiles of $\mathrm{CD}_{4}$ counts have been analyzed. Due to poor documentation of data, the details regarding HIV status of spouse and children, occupation/ income and educational status could not be obtained.

\section{Results}

Table 1: Year wise percentage of HIV seropositivity among women

\begin{tabular}{|c|c|c|c|}
\hline Year & $\begin{array}{c}\text { No of women attending } \\
\text { ICTC }\end{array}$ & $\begin{array}{c}\text { No of women Positive } \\
\text { for HIV }\end{array}$ & \% Positivity \\
\hline $\begin{array}{c}\text { 2007- } 2008 \\
\text { Apr-Mar }\end{array}$ & 1569 & 333 & 21.22 \\
\hline $\begin{array}{c}\text { 2008- 2009 } \\
\text { Apr- Mar }\end{array}$ & 1352 & 342 & 25.3 \\
\hline 2009- 2010 & 2495 & 362 & 14.5 \\
Apr-Mar & 2329 & & 12.66 \\
\hline 2010- 2011 & & 295 & \\
\hline Apr- Mar & & & \\
\hline
\end{tabular}

$P<0.001$, highly significant

The year wise attendance of women to ICTC and their HIV sero positivity are shown in Table- I. There is a significant increase in the attendance over the period of 04 years. However the percentage of sero positivity has declined significantly as shown in the $4^{\text {th }}$ column of Table -1 . 
Table 2: Age wise \& Progress wise distribution of women on ART

\begin{tabular}{|c|c|c|c|c|c|c|}
\hline Sr no & $\begin{array}{c}\text { Age } \\
\text { Group }\end{array}$ & $\begin{array}{l}\text { Total No } \\
\text { of women } \\
\text { on ART }\end{array}$ & $\begin{array}{c}\text { Women with } \\
\text { Increasing CD4 } \\
\text { counts No / \% }\end{array}$ & $\begin{array}{c}\text { Women with } \\
\text { Decreasing CD4 } \\
\text { counts No / \% }\end{array}$ & $\begin{array}{c}\text { Deaths No } \\
\text { / \% }\end{array}$ & $\begin{array}{c}\text { Transfer No / } \\
\%\end{array}$ \\
\hline \multirow{2}{*}{1} & \multirow{2}{*}{$15-25$} & \multirow{2}{*}{267} & 216 & 7 & 28 & 16 \\
\hline & & & 80.90 & 2.60 & 10.50 & 6 \\
\hline \multirow{2}{*}{2} & \multirow{2}{*}{$26-35$} & \multirow{2}{*}{653} & 531 & 7 & 95 & 20 \\
\hline & & & 81.30 & 1.30 & 14.50 & 3 \\
\hline \multirow[t]{2}{*}{3} & \multirow{2}{*}{$36-45$} & \multirow{2}{*}{337} & 262 & 11 & 55 & 9 \\
\hline & & & 77.70 & 3.30 & 16.30 & 2.70 \\
\hline \multirow{2}{*}{4} & \multirow{2}{*}{$>45$} & \multirow{2}{*}{90} & 67 & 5 & 17 & 1 \\
\hline & & & 74.40 & 5.50 & 18.90 & 1.10 \\
\hline
\end{tabular}

chi-square value 10.903, $\mathrm{p}<0.02$.

In Table - 2, women on ART are studied in different age groups among whom redistribution was done based on increasing and decreasing $\mathrm{CD}_{4}$ counts, deaths and transfers. There is a significant percentage of responsiveness to therapy in the younger age groups (15-25 years and 26-35 years ) evidenced by increasing $\mathrm{CD}_{4}$ counts.

Table 3: Opportunistic infections among deaths while on ART

\begin{tabular}{|c|c|c|c|}
\hline Sl. No & Cause of Death & No. of deaths & Percentage \\
\hline $\mathbf{1}$ & Tuberculosis & 32 & 16.4 \\
\hline $\mathbf{2}$ & Ari & 27 & 13.8 \\
\hline $\mathbf{3}$ & Jaundice & 27 & 10.8 \\
\hline $\mathbf{4}$ & Diarrhoea & 15 & 7.7 \\
\hline $\mathbf{5}$ & Candidiasis & 21 & 12.8 \\
\hline $\mathbf{6}$ & Gross anemia & 48 & 24.6 \\
\hline $\mathbf{7}$ & Not documented & 195 & 100 \\
\hline $\mathbf{8}$ & Total no of Deaths & & \\
\hline
\end{tabular}

Chi square test 23.15, p<0.005, Significant.

Table - 3 depicts the range of opportunistic infections recorded as cause of death among patients while on ART. Tuberculosis is significant in being the commonest opportunistic infection, with a percentage of 16.4. Acute respiratory infection as cause of death accounted for $13.8 \%$. Jaundice is documented in $13.8 \%$ of cases. However the etiological diagnosis has not been made. The percentages are represented in Figure-1. 
Table 4: Comparison of percentages of deaths at various ranges of CD4 Counts

\begin{tabular}{|c|c|c|c|}
\hline Sr. No & $\begin{array}{c}\text { Range of CD 4 count } \\
\text { (no/cumm) }\end{array}$ & Number of deaths & Percentage \\
\hline $\mathbf{1}$ & $0-50$ & 53 & 27.18 \\
\hline $\mathbf{2}$ & $51-100$ & 35 & 17.9 \\
\hline $\mathbf{3}$ & $101-150$ & 28 & 16.92 \\
\hline $\mathbf{4}$ & $151-200$ & 20 & 10.26 \\
\hline $\mathbf{5}$ & $201-250$ & 14 & 7.18 \\
\hline $\mathbf{6}$ & $251-300$ & 12 & 6.15 \\
\hline $\mathbf{7}$ & $>300$ & & \\
\hline
\end{tabular}

In Table -4 , an attempt is made to tabulate the ranges of $\mathrm{CD}_{4}$ counts among patients who died while on ART. Maximum number of deaths $(27.18 \%)$ were associated with counts as low as $0-50$. Deaths occurred even at $\mathrm{CD}_{4}$ counts above 200 , as shown in the table. However, there is a gradual decrease in the percentages of deaths at higher range of $\mathrm{CD}_{4}$ counts.

As a baseline parameter, the $\mathrm{CD}_{4}$ count of $50 \mathrm{HIV}$ seronegative women between the ages of 15-45 years are estimated. The average is 972 cells $/ \mathrm{mm}^{3}$, which is correlating with Murugavel et al ${ }^{5}$, a study done in healthy adult population in Chennai, India.

\section{Discussion}

Since more than two decades, the AIDS pandemic in India has grown as a major public health problem with medical, psychosocial and economic consequences at individual and at national level.

The median HIV prevalence in A.P. is $1.25 \%$ in low risk groups, being higher than all the other states in India ${ }^{6}$. Apart from factors such as sexual practices, the other risk factors in females are male - female age differences, anatomical peculiarity of genitalia, asymptomatic S.T.Ds in women, blood transfusions etc. In India, women are in a poor position to question their husbands about their extramarital encounters, to negotiate condom use or refuse to have sex. Forced sexual encounters invariably end in bruises and injuries to genitalia, favoring transmission of HIV.

Percentage of HIV seropositivity among women attending ICTC has a gradual decline, from $21.2 \%$ to $12.7 \%$. This is in coincidence with the control of HIV epidemic in India with effective national policies as well as involvement of voluntary organisations in the control of the epidemic.

More awareness regarding HIV is another reason responsible for large number of person are coming for volunteer testing.

$\mathrm{CD}_{4}$ cells are the major cell types affected. ART reconstitutes the immune system and improves survival ${ }^{7}$. However the rate and extent of $\mathrm{CD}_{4}+\mathrm{T}$ cell recovery varies widely. In the present study (Table-II), a significant improvement of $\mathrm{CD}_{4}$ counts is observed in the younger age groups 15-25 years and 26-35 years. The percentage of older women who have responded to ART by increasing $\mathrm{CD}_{4}$ counts is however less compared to the younger age group.

For reasons which are yet to be identified, younger women responded better than older women to ART as per the data. According to Shaeferet $\mathrm{al}^{8}$, younger patients have a significantly larger increase in $\mathrm{CD}_{4}$ cells after 48 weeks of ART. This is probably related to a better functioning

Available online at: www.ijmrr.in 187 | P a g e


immune system in the young, reacting positively to compensate for the depleting $\mathrm{CD}_{4}$ cells. Such mechanism may not be possible as age advances, due to decompensated immune system.

In the present study tuberculosis occupied the first place with a percentage of $16.4 \%$ as the commonest Opportunistic Infection causing death in HIV positive individuals while still on ART. As already documented, TB- HIV confection is a major world health problem and according to WHO, nearly a quarter of the HIV deaths were due to tuberculosis in 2007. In developing countries like India, tuberculosis presents as a pulmonary disease. It is also a well documented fact that the most common OI in HIV infected is pulmonary tuberculosis ${ }^{9}$. Risk of death in HIV- TB patients is 3.5 times greater than the risk in HIV positive patients without $\mathrm{TB}$ with matched $\mathrm{CD}_{4}$ counts ${ }^{10}$. In other countries like Uganda, HIV- TB was $1.4 \%$ among the total HIV infected patients ${ }^{11}$. In a study at Baltimore, USA, the incidence of HIV-TB was $3.6 \%{ }^{12}$. A study in Sub Saharan Africa ${ }^{13}$ has shown that HIV - TB patients have a significantly lower median $\mathrm{CD}_{4}$ count increase, compared to the non TB counterparts while on ART.

In the present study (Table - IV), as much as $27.18 \%$ of deaths while on ART occurred with a $\mathrm{CD}_{4}$ count range of $0-50$ cells $/ \mathrm{mm} 3$. The number and percentage of deaths were lower at higher ranges of $\mathrm{CD}_{4}$ counts. Literature is not available regarding the average $\mathrm{CD}_{4}$ counts at the time of death of Indian patients on ART.

However, it can be stated that the individual risks and complications associated with Opportunistic Infection determine the time of death and not $\mathrm{CD}_{4}$ counts alone. Opportunistic infections always occur at lower $\mathrm{CD}_{4}$ counts, and further reduce the immune competence of the patients.

\section{Conclusion}

There are very few studies on HIV disease among Indian women. In spite of active intervention by Government of India and NGOs, only about $80 \%$ of women improved with
ART as per the present study. Therefore it might be stated that special programmes are needed to focus on early detection, early initiation of ART, counseling regarding barrier methods applicable to females and above all, monitoring therapy among women in India to achieve better survival rates with ART.

Funding: Nil

\section{Conflict of interest: Nil}

\section{Permission from IRB: Yes}

\section{References}

1. Usha KB, Rewari BB. Diagnosis and management of HIV/ AIDS, a clinician's perspective. 1st ed. B.I Publications Private Limited; 2004. ch 18 P. 264-279.

2. Gilks CF. Natural history of HIV-AIDS. In: Manson's Tropical Diseases. $21^{\text {st }}$ ed. W B Saunders: 2003 .Ch 20 P. 411.

3. Gangakhedkar RR, Bentley ME, Divakar AD .Spread of HIV infection among married monogamous women attending STD clinics in India . JAMA 1997; $278: 2090$ 2092.

4. Patubidn VG, Daftary SN. Natural course of HIV. In: Shaw's Text Book of Gynecology. 15 ${ }^{\text {th }}$ ed. Elsevier's Publications; 2010. Ch 11: 148 .

5. Murugavel KG, Balakrishnan P, MohankrishnanJ, Solomon SS, Shankar EM ,. Establishment of Tlymphocyte subject reference intervals in a healthy adult population in Chennai, India. Indian $\mathrm{J}$ Med Res 2009;129:59-63.

6. Usha KB, Rewari BB. Diagnosis and management of HIV/ AIDS, a clinician's perspective. 1st ed. B.I publications Private Limited ; 2004. ch 18 P. 2-9.

7. Wilkins EGL.Humanimmuno deficiency virus infection and the Human acquired immunodeficiency syndrome. Davidson's Principles and Practice of Medicine. $20^{\text {th }}$ ed. 
John A.A Hunter ,Churchill Livingstone- Elsevier publication 2006; ch14 P. 399-401.

8. Shaefer M, James D, Henry Z, Amy C, Martin G, James G. Effect of age on baseline CD4+ and CD8+ cells and response to ART over 48 weeks in a large clinical trial database. Presented at the $1^{\text {st }}$ Int. Workshop on HIV \& Aging, 4-5 Oct 2010, Baltimore, USA.

9. Solmon S, Kumarswamy, Anuradha S, Vennila R, Pal JA. TB and HIV infection - an association. Indian J Med Microbiol 1994, 12: $313-4$.

10. Kumarasamy N, Solomon S, Flanigan TP, Hemalatha R, Thyagarajan SP, Mayer KH. Natural history of human immunodeficiency virus infection among adults in Mumbai. Nat Med J India 2003;16: 126-31.

\section{How to cite this article?}

Gayathri V, Ramanamma VM. A Study of HIV Disease Course Among Rural Women Receiving ART. Int J Med Res Rev 2013;1(4):184-189. doi: 10.17511/ijmrr.2013.i04.07
11. Nakanjako D, MayanjaKH ,Ouma J , Wanyenze R, Mwesigine D, Namle A, Sse MJ, Senkusu J, Colebunders R, Kamya MR :Tuberculosis and human immunodeficiency virus co-infection and their predictors at a hospital based HIV/AIDS clinic in Uganda. Int $\mathrm{J}$ Tuberc lung Dis 2010;14: 1621-8.

12. Martinson NA, Barnes GL, Moultion LH, Msandiwa R, Hausler H, Ram M, Mclntyre JA, . New regimens to prevent tuberculosis in adults with HIV infection. $\mathrm{N}$ Eng $\mathrm{J}$ Med 2011; 365 (1) ;11-20.

13. Hermans SM, Kiragga AN, Schafer P, Kambugu A, Hoepelman A1, Manabe YC. Incident tuberculosis during antiretroviral therapy contributes to suboptimal immune reconstitution in a large urban HIV clinic in sub-saharan Africa.http://blogs.plos.org/plos/2010/10/epigenetics2010-a-new-collection-from-the-plos-journals/. 